\title{
El papel de Abraham ibn Ezrá en la divulgación de los «juicios» de la astrología en las lenguas hebrea y latina
}

Shlomo SELA

Tel Aviv University

A partir del siglo XII hacen su aparición en la Europa occidental latina dos nuevos términos que encarnan el concepto de la influencia astrológica sobre el hombre y el mundo: el primero es el término latino iudicia y el segundo es el vocablo hebreo mišpatim (משפטים), cuyo significado de 'juicios de la astrología' es similar al de la palabra latina. La voz latina iudicia, dotada de significado astrológico, no se encuentra en la literatura latina clásica, pero sí a partir del siglo XII y su uso se divulgará durante la Edad Media y el Renacimiento, cristalizando en el marco de la cultura europea-latina en la expresión astrologia iudicaria ${ }^{1}$. Igualmente la palabra hebrea mišpatim con un significado netamente astrológico no aparece antes del siglo XII y se divulgará en la literatura hebrea medieval.

Dentro de una concepción del mundo que adjudicaba a la praxis astrológica un carácter netamente científico y en un contexto cultural y mental que otorgaba a las predicciones astrológicas una importancia fundamental para el conocimiento del futuro y del pasado, la pregunta sobre el origen de tales

1 Aun hoy en día, cuando la reputación científica de la astrología ha decaído enormemente, la expresión continúa usándose en las lenguas modernas derivadas del latín; cf. el uso de la expresión astrología judiciaria en español, astrologie judiciarie en francés, astrologia iudiciaria en italiano y judicial astrology en inglés. 
términos tiene gran interés para conocer los procesos formativos de una interesante faceta de la historia cultural y mental de la Edad Media.

Este artículo intenta esclarecer el papel que Abraham ibn Ezrá desempeñó en la introducción en hebreo y en latín de los términos mišpatim y iudicia con significado netamente astrológico.

Los dos vocablos -iudicia en latín y mišpatim en hebreotienen su origen en la expresión árabe ahkâm al-nujûm ('juicios de las estrellas') ${ }^{2}$ y se introdujeron de forma paralela en la sociedad judía y en la civilización cristiano-latina de Europa occidental como parte del proceso de transmisión al Occidente latino de las ciencias árabes desarrolladas en Al-Ándalus, por medio de la redacción y traducción de textos científicos árabes al latín y al hebreo ${ }^{3}$.

Un breve examen de la trayectoria literaria de Abraham ibn Ezrá aclara hasta qué punto desempeñó el papel de transmisor

\footnotetext{
${ }^{2}$ Según la opinión de R. LEMAY, la raíz árabe h. $k . m$ sirvió de origen al término latino iudicia ( The True Place of Astrology in Medieval Science and Philosophy», en Astrology, Science and Society, ed. P. CURRY [Suffolk 1987] págs. 57-73). Véanse también C. A. NALlino, "Astrology", en First Encyclopedia of Islam (Leiden 1987) vol. I págs. 494-502; y S. PINES, «The Semantic Distinction between Astronomy and Astrology according to Al-Biruni», Isis 55 (1964) págs. 343-349. Puede verse un ejemplo del uso de la expresión árabe ahkâm al-nujûm en Al-Biruni, The Book of Instruction in the Elements of the Art of Astrology, ed. R. RAMSAY WRIGHT (London 1934) pág. 317.

${ }^{3}$ Uno de los principales focos de esa transmisión fue la ciudad de Toledo a mediados del siglo XII. Bajo la dirección de don Raimundo, arzobispo de esa ciudad, actuaron varios traductores de origen judío entre los que destaca Iohannes Avendehut Israelita, también llamado Juan de Sevilla; véase especialmente J. GIL, La escuela de traductores de Toledo y los colaboradores judios (Toledo 1985) págs. 30-38. Entre las traducciones realizadas por Iohannes Avendehut Israelita que allí se mencionan, pueden destacarse los títulos de las siguientes obras en los cuales aparece el término latino iudicia como traducción directa de la expresión árabe ahkâm al-nujûm: 1) Libellus Ysagogicus Abdilazi, qui dicitur Alchabitus ad Magisterium judicorum astrorum, que es la traducción de Kitâb al-Madhal ila sinâ 'ât ahkâm al-nujûm;2) De judiciis nativitatibus liber unus, de Abú Alí al-Hiyat, traducido en 1153; y 3) De consuetudinis in judiciis astrorum, atribuido a Claudio Tolomeo. Véase también en The Astrological History of Mâshâ'llâh, eds. E. S. KenNedy y D. Pingree (Cambridge 1971) pág. 145 la introducción al Liber de nativitatibus de Mâšâ'llâh: «Dixit Messeallah quod inter omnes libros astonomiae non invenitur utilior libro nativitatum neque tam bonus in iudicis».
} 
en la sociedad judía y latina de ideas y contenidos científicos provenientes de la cultura árabe. Abraham ibn Ezrá abandonó la Península Ibérica y en 1140 , cuando tenía casi 50 años de edad, partió hacia Roma después de haber absorbido en AlÁndalus ricos y variados contenidos de las ciencias árabes. En su estancia en Italia, Francia e Inglaterra produjo una extensa y multifacética obra literaria, principalmente en lengua hebrea pero también en latín. Si nos limitamos a la literatura en prosa, la obra de Abraham ibn Ezrá abarca tres campos principales: a) comentarios a la mayoría de los libros bíblicos, a veces en dos versiones diferentes; b) monografías teológicofilosóficas; y c) un extenso corpus científico que comprende: obras astrológicas, astronómicas y matemáticas; manuales para el uso del astrolabio y de las tablas astronómicas; tratados científicos traducidos del árabe al hebreo ${ }^{4}$; y tratados de gramática hebrea. Con la redacción de esas obras no sólo cumplió un papel importante en el llamado «renacimiento científico del siglo XIı» ${ }^{5}$, sino que también fué un pionero en el uso de la lengua hebrea y desempeñó un papel relevante en el recientemente denominado "process of secularization of the Holy tongue and the formation of "Jewish science", written essentially in Hebrew» ${ }^{6}$.

\footnotetext{
${ }^{4}$ En mi libro Scientific Data in the Exegetical-Theological Work of Abraham Ibn Ezra: Historical Time and Geographical Space Conception (Tesis doctoral: Univ. de Tel Aviv, 1997) [en hebreo] determino que el corpus científico de Abraham ibn Ezrá lo componen aproximadamente veinticinco obras diferentes. Vid. también José María Millás VALLICROSA, «The Work of Abraham ibn-Ezra in Astronomy» [en hebreo], Tarbiz 9/3-4 (1938) págs. 306-320. Al igual que sucede con sus comentarios bíblicos, Ibn Ezrá compuso sus obras científicas en varias versiones: así, por ejemplo, el Libro de los fundamentos de las tablas astronómicas, del que hizo cuatro versiones diferentes, dos en hebreo y dos en latín. De ello me ocupo más adelante.

${ }^{5}$ Ch. Haskins, Studies in the History of Medieval Science (Cambridge 1927).

- Véase especialmente R. BARKAI, A History of Jewish Gynaecological Literature in the Middle Ages (Leiden 1998). En el primer capítulo de su libro Barkai analiza las razones que llevaron a los intelectuales judíos a abandonar paulatinamente el árabe como lengua de las ciencias y a adoptar a partir del siglo XII la lengua hebrea como apta para la redacción de tratados científicos. En resumen, las causas enumeradas son: a) las invasiones de Al-Ándalus por los ultrarreligiosos almorávides (1090) y almohades (1145), que dieron fin a una época de moderación y tolerancia; b) la imposibilidad por parte de los judíos del Occidente latino de acceder a la literatura científica escrita en latín; c) el deprimido estatus jurídico
} 
En este artículo pretendo alcanzar los tres objetivos principales que a continuación enumero:

1) Demostrar que Abraham ibn Ezrá fue el primero en utilizar el término mišpatim en la lengua hebrea con el significado de 'juicios de la astrología' 7, introduciendo el nuevo término en los diferentes géneros de su producción literaria: traducciones del árabe al hebreo, tratados científicos redactados en hebreo y en latín, y comentarios bíblicos y monografías teológico-científicas.

2) Señalar otros dos hechos en relación con la creación de ese nuevo término hebreo. En primer lugar, esta creación léxica no es un hecho aislado, sino un ejemplo concreto de un fenómeno general en la obra literaria de Abraham ibn Ezrá: la invención de un léxico científico hebreo basado explícita y conscientemente en el vocabulario bíblico. En segundo lugar, si el término mišpatim arraigó en las obras de Abraham ibn Ezrá se debe a que los significados de la palabra reflejaban facetas esenciales de su concepción del mundo.

3) Mostrar que después de la muerte de Abraham ibn Ezrá los términos mišpatim y iudicia con acepción astrológica se introdujeron en el hebreo y en el latín medievales por medio y como efecto directo de la difusión de su obra literaria. En tal sentido me limitaré a rastrear la primera etapa de tal proceso (finales del siglo XII y siglo XIII).

de los judíos, que les impedía la instrucción formal en las universidades; y d) la tendencia «nacionalista» de los intelectuales judíos que deseaban mostrar que el hebreo no era menos apto que el latín o el árabe para la transmisión de contenidos científicos.

7 I. KLATZKIN, en Oșar ha-munahim ha-filosofiyim ve-antologuia filosofit (Berlín 1928) vol. II págs. 302-303, hace alusión a la expresión «juicios de las estrellas» pero no se menciona a Abraham ibn Ezrá como uno de los autores que la utilizó. A fines del siglo pasado, D. Rosin, «Die Religionsphilosophie Abraham Ibn Esra's», Monatsschrift für Geschichte und Wissenschaft des Judentums 42 (1898) págs. 17 ss y 43 (1899) págs. 22ss: 42 pág. 248, sugirió una relación entre la expresión latina astrologia iudicaria y los términos griegos apotelesmatike ('astrología') y apotelesmatikoi ('astrólogos') sin advertir el origen árabe de la expresión. Sin embargo, en ese mismo lugar D. Rosin reconoció un lazo entre la expresión hebrea mišpeté ha-mazalot, utilizada por Ibn Ezrá en su libro Yesod mor'á y en sus comentarios bíblicos, y la expresión latina astrologia iudicaria. 
1. EL TÉRMINO MIŠPATIM EN LA TRADUCCIÓN HEBREA DEL COMENTARIO DE IBN AL-MUTTANA A LAS TABLAS ASTRONÓ$M I C A S$ DE AL-JWARIZMI

Antes de entrar de lleno en mi exposición, es necesario hacer una digresión para examinar la forma en que Abraham bar Hiyá vertió a la lengua hebrea contenidos astrológicos. Bar Hiyá, contemporáneo y conocido de Abraham ibn Ezrá, tuvo como él acceso a las ciencias árabes y en sendos tratados científicos en hebreo trató de diferentes temas de astronomía, matemáticas y astrología, todo lo cual propiciaba que él hubiera sido el innovador del significado de mišpatim con valor astrológico.

Sin embargo, del examen de las obras científicas de Abraham bar Hiyá se desprende que no usa el término mišpatim, sino que prefiere otras palabras hebreas alternativas ${ }^{8}$.

Como ya he señalado, mišpatim con acepción astrológica proviene de la expresión árabe ahkâm al-nujûm y por lo tanto las traducciones del árabe al hebreo sirven como un excelente punto de arranque de nuestra pesquisa. Efectivamente, la palabra se encuentra en la traducción que hizo Ibn Ezrá del Comentario de Ibn al-Muttana a las Tablas astronómicas de al-Jwarizmi. El original árabe se ha perdido, pero se han conservado tres traducciones diferentes, una al latín y dos al hebreo ${ }^{9}$. Una de las dos versiones hebreas pertenece sin duda a

\footnotetext{
${ }^{8}$ En lugar de mišpatim o de la expresión mišpeté ha-kojabim, Bar Hiyá prefirió usar guezerot (גזרות) 'sentencias' o guezerot ha-kojabim (גזרות הכוכבים) 'sentencias de las estrellas' para, según mi opinión, traducir el árabe ahkâm al-nujûm. Véanse ejemplos del uso de tales expresiones en la «Iguéret R' Abraham bar Hiyá ha-nasí še-katab le-R' Yehudá Barzilay 'al šeelá be-Kaldiyim», en Festschrift Adolf Schwarz (Berlín-Viena 1917) sec. hebrea págs. 23-36; y Meguilat ha-megalé, ed. S. POZNANSKY (Berlín 1921) págs. 112-115.

${ }^{9}$ M. STEINSCHNEIDER descubrió la versión hebrea y la publicó con una traducción al alemán en «Zur Geschichte der Uebersetzungen aus dem Indischen ins Arabische und ihres Einflusses auf die arabische Leteratur», Zeitschrift der deutschen Morgenländischen Geselschaft 24 (1870) págs. 325-392 y 25 (1871) págs. 388-428; allí adjudicó erróneamente la autoría del texto árabe original a Muhamad ibn Ajmad Al-Biruni. D. SMITH y Y. GinSBURG, en su artículo «Rabbi ben Esra and the Hindu-Arabic Problem», The American Mathematical Monthly 25 (1918) págs. 99-108, tradujeron el texto al inglés repitiendo la opinión de Steinschneider sobre su autor. El asunto se complicó aún más cuando Ch. HASKINS afirmó en Studies in the History of Medieval Science (Cambridge 1927) págs. 67-81 que el
} 
Abraham ibn Ezrá, ya que agregó una notable introducción de su puño y letra en la que se identifica como «Abraham ibn Ezrá el sefardí» y relata la historia de la transmisión de las ciencias de la India a la cultura árabe.

Como en sus restantes obras científicas, en esta obra tenía Ibn Ezrá que enfrentarse a un grave problema: ¿cómo utilizar el hebreo, una lengua limitada hasta ese momento al vocabulario bíblico, al léxico de uso ritual o la de la interpretación bíblica o talmúdica, para traducir una obra astronómica redactada en árabe? En su traducción puede observarse cómo solucionó el problema, siendo una de sus características la creación de un léxico científico hebreo basado explícita y conscientemente en el vocabulario bíblico. De ese léxico se pueden presentar tres ejemplos notables:

1) El vocablo mușac (מוצק), que Abraham ibn Ezrá tomó de $J o b \quad 36: 16^{10}$ y que en su opinión representa inicialmente el concepto de «centro geométrico», pero cuyo campo semántico se amplía para incluir también el significado de 'tierra inmóvil en el centro de un cosmos esférico', noción clave en la concepción científica del mundo en la Edad Antigua y en la Edad Media ${ }^{11}$.

autor era Al-Fargani. Por último, Millás VAllicrosA «La obra astronómica» págs 306-309 estableció que el autor era Ajmad ibn Al-Muttana ibn Abd-Al-Krim. Las dos versiones hebreas se publicaron en Ibn al-Muthannâ's Commentary on the Astronomical Tables of al-Khwarizmi: Two Hebrew Versions, ed. y trad. Bernard R. GoldSTEIN (New Haven-London 1967); y de la latina se encargó E. MiLlás VAllicrosa, El comentario de Ibn al-Mutanna a las Tablas Astronómicas de alJwârizmî: Estudio y edición crítica del texto latino, en la versión de Hugo Sanctallensis (Madrid-Barcelona 1963). Sobre la transmisión de las tablas de AlJwarizmi debe consultarse también la reseña de J. SAMSó en Las ciencias de los antiguos en Al-Andalus (Madrid 1992) págs. 84-93.

${ }^{10}$ En su comentario a ese versículo explica Ibn Ezrá el especial significado geométrico que tiene el término musac, poniéndolo en relación con el sentido כambién geométrico de la palabra bíblica rahab (רח רואב הוא הקו הסובב העגולה כ'Ya que rahab es el perímetro del círculo y muṣac es el punto [central]'.

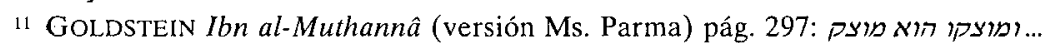
הארץ ויקרא גלגל המזלות וגלגל אחר יקרא גלגל הגבהותומוצקו רחוק ממוצק הארץ הat. Además de utilizar profusamente el término muṣac en sus obras científicas, Abraham ibn Ezrá lo usa también en sus comentarios bíblicos, como por ejemplo en su comentario a Ecl 3:15. Véanse las importantes observaciones al respecto de Mariano GómEz ARANDA sobre el «punto central estable» en su artículo «Teorías astronómicas y 
2) La expresión nahaš baríah (נחש בריח), que Abraham ibn Ezrá toma de $J o b$ 26:13, y que a su juicio representa el punto de intersección entre dos de los círculos que la ciencia medieval adoptó para describir las trayectorias de los planetas o para representar el concepto tolomeico del «doble movimiento celestial» ${ }^{12}$.

3) El término mišpatim, que según veremos más adelante tomó Abraham ibn Ezrá de Sal 19:10, se emplea en un interesante pasaje en el cual se describe una doctrina hindú que explica las extrañas trayectorias de los planetas -los cuales se adelantan, retroceden o se quedan inmóviles- utilizando la teoría de que los planetas están ligados al sol por medio de «lazos similares a los que se [utilizan para] uncir los caballos o bestias de carga a un carro» ${ }^{13}$. Al final del pasaje escribe Abraham ibn Ezrá lo siguiente:

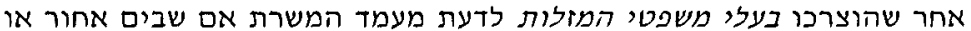

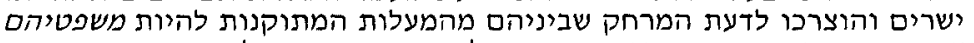

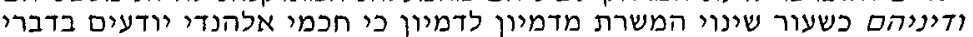

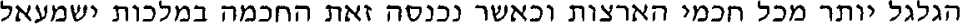

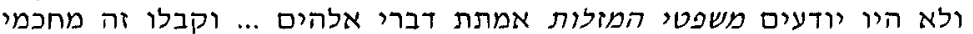
הינדיאה ביזו בקבלה וקרא משוהו קישורים 14

astronómicas y astrológicas en el Comentario de Abraham Ibn Ezra al libro de Eclesiastés», Sefarad 55 (1995) págs. 257-272: pág. 263; debe consultarse también su edición crítica El comentario de Abraham ibn Ezra al libro del Eclesiastés (Madrid 1994) págs. 54-55, *31-32.

12 Goldstein Ibn al-Muthannâ (versión Ms. Parma) pág. 296 (los subrayados en

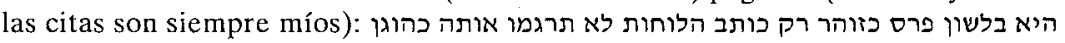

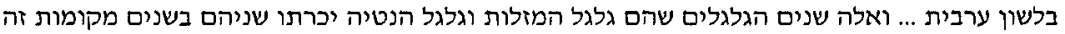

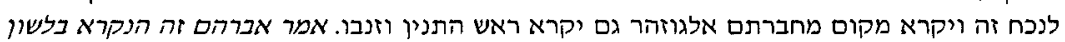
ל הקדש נחש בריח "El término algozhar] es en lengua persa kazohar, pero el redactor de las tablas no lo tradujo correctamente al árabe ... y esos dos círculos, que son el círculo del zodíaco y el círculo de declinación, se cortan en dos lugares opuestos, y el lugar de intersección se denomina algozhar o también «la cabeza y la cola del dragón». Dijo Abraham: Es lo que se llama nahaš baría en la lengua santa'.

Debe señalarse que en este fragmento Abraham ibn Ezrá está tan preocupado por el origen bíblico de los términos científicos que traduce, que abandonando su función de traductor, adopta la de comentarista con el objetivo de señalar enfáticamente que la expresión bíblica nahaš baríah es la exacta traducción del término persa kazohar, o sea caput et cauda draconis.

13 Sobre esta teoría, que representa un primitivo heliocentrismo, véase D. Pingree, «Astronomy and Astrology in India and Iran», Isis 54 (1963) págs. 229-246: pág. 242.

14 GoldSTEIN Ibn al-Muthannâ págs. 283-285. 
Cuando necesitaron los sabios de los juicios de los signos del zodíaco conocer la posición de los planetas, [es decir,] si retroceden o avanzan, y necesitaron averiguar la distancia que hay entre ellos en grados normalizados con la intención de que sus juicios y veredictos [Job 36:17] estuvieran en relación directa con el cambio de dirección de los planetas de fase en fase, ya que los sabios de la India saben sobre los asuntos de las esferas más que los sabios de cualquier otro país y cuando penetró la sabiduría [de la India] en los reinos de Ismael [los árabes] y no conocían los juicios de los signos del zodíaco de acuerdo a la verdad de la palabra divina ... adoptaron esta [doctrina] recibiéndola de los sabios de la India y la denominaron [doctrina de] los lazos.

En este pasaje destacan tres expresiones derivadas del término mišpatim ('juicios'): ba alé mišpeté ha-mazalot ('conocedores de los juicios de los signos del zodíaco'); mišsatehem ve-dinehem ('sus juicios y veredictos'); y mišpeté ha-mazalot ('juicios de los signos del zodíaco'). Se observa que Abraham ibn Ezrá no aplica simplemente el término mišpatim, sino que le agrega un matiz bíblico cuando usa la expresión mišpatim $v e$-dinim ('juicios y veredictos') que tiene su origen en el texto bíblico (Job 36:17; Sal 9:5; Jer 21:12).

Sin embargo, y a pesar de que la fuente árabe no se ha conservado, puede afirmarse con un alto grado de probabilidad que Abraham ibn Ezrá tradujo literalmente el término mišpatim del árabe. Esta hipótesis puede confirmarse si se compara el fragmento con los pasajes paralelos de las dos restantes traducciones de la misma obra. También en la segunda traducción al hebreo, la versión denominada Michael, el traductor empleó el vocablo mišspatim en diferentes combinaciones ${ }^{15}$, mientras que en la traducción latina Hugo Sanctallensis se sirvió de la expresión re iuditia ${ }^{16}$.

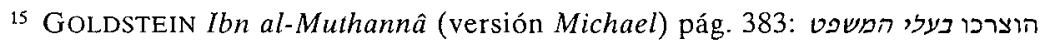

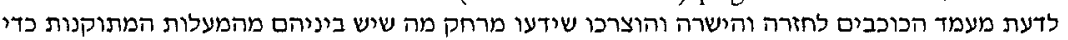

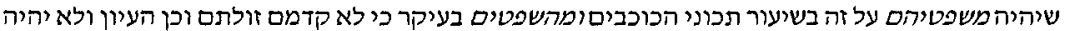

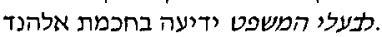

${ }^{16}$ Millás Vallicrosa Tablas Astronómicas págs. 120-121: «unde necesse fuit astrorum peritis stellarum moras ad retrogradandum et dirigendum, sed etiam que sit inter ipsas sub certis gradibus et rectis distantia ut eorum supra huiusmodi re iuditia ad statum stelle atque modum penitus referantur et ab hiis que in radice priori fuerant, nulla tenus varientur. Indorum enim sapientibus nullus antiquorum potuit comparari». 
Así también debe señalarse que en ese fragmento el término mišpatim se enfoca desde dos ángulos diferentes. Por un lado, esta palabra representa un término técnico de clara connotación científica: los «sabios de los juicios de los signos del zodíaco» están ocupados en «conocer las estaciones planetarias» o en «averiguar las distancias entre los planetas en grados normalizados», y el objetivo es que sus juicios y veredictos, o sea sus predicciones astrológicas, no se hagan negligentemente sino de acuerdo con los preceptos de la astronomía, es decir, «en relación directa con el cambio de dirección de los planetas de fase en fase». Pero, por otro lado, es posible observar que el término mišpatim se usa desde una perspectiva teológica: «los juicios de los signos del zodíaco» están «de acuerdo con la verdad de la palabra divina».

Esta observación es importante ya que nos insinúa que el término mišpatim no sólo posee un significado estrechamente técnico y científico, sino que pertenece también a la esfera de la acción divina. No debemos olvidar que Ibn Ezrá está traduciendo y por tanto no expresa sus propias ideas; sin embargo, luego comprobaremos que adoptó esa perspectiva científicoteológica del término mišpatim y la usó especialmente en sus comentarios bíblicos.

\section{USOS DE LOS TÉRMINOS MIŠPATIM Y DINIM ('JUICIOS' Y 'VEREDICTOS' DE LA ASTROLOGÍA) EN LAS OBRAS CIENTÍ- FICAS DE ABRAHAM IBN EZRÁ}

El término mišpatim ocupa un lugar de importancia en las obras científicas de Abraham ibn Ezrá, aunque a veces prefiere el uso del substantivo bíblico dinim (דינים) 'veredictos' o del verbo bíblico la-din (לדין) 'dar un juicio o veredicto'. Puede comprobarse este hecho en la introducción a la primera versión del tratado astrológico Séfer ha-Moladot ('Libro de las natividades'), que trata sobre la astrología personal y la interpretación del horóscopo individual. Así comienza nuestro autor la obra, que aún permanece inédita:

אמר ר' אברהם הספרדי כל משכיל בחכמת משפטי המזלות ואיננו יודע מהחכמה

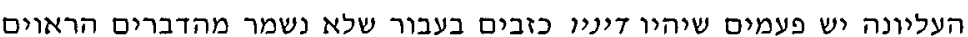

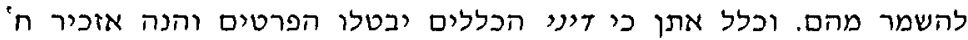
דרכים. הא' שיש לו לדעת הנולד מאיזה עם עם הוא כי אם היה המולד לישראלי 


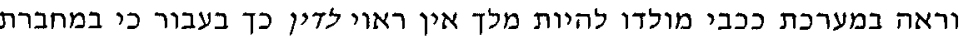

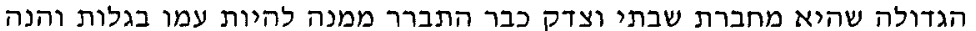

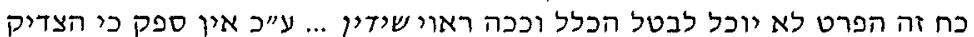

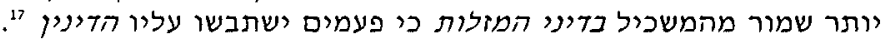

Dijo R. Abraham, el sefardí: A todo aquel que se haya instruido en la ciencia de los juicios de los signos del zodíaco y que no conozca la sabiduría superior le ocurrirá a veces que sus veredictos serán falsos, ya que no se ha guardado de aquellas cosas de las que hay que cuidarse. $\mathrm{Y}$ voy a dar una regla [importante]: los veredictos generales anulan los particulares; y mencionaré [en este sentido] ocho ejemplos. [Según] el primero, debe conocer a qué pueblo pertenece el recién nacido, ya que si se trata del horóscopo de un israelita y ve en la carta astral de su horóscopo que será rey, no deberá dictar ese veredicto, pues de la gran conjunción, que es la conjunción de Saturno y Júpiter, ya ha quedado claro que su pueblo ha de permanecer en el exilio; y como la fuerza de ese individuo no puede anular la general, así debe dictarse el veredicto ... Por lo tanto, es indudable que el piadoso está más protegido [de las calamidades procedentes de las estrellas] que el instruido en los veredictos de los signos del zodíaco, ya que a veces sus veredictos serán erróneos.

Se observan en este pasaje diferentes giros derivados de la expresión bíblica mišpatim ve-dinim ('juicios y veredictos'), cuyo significado es similar al que aparece en el pasaje extraído de la traducción de Abraham ibn Ezrá al Comentario de Ibn al-Muttana a las Tablas astronómicas de al-Jwarizmi. Sin entrar en la interpretación de este interesante texto, notamos que también aquí los términos mišpatim ve-dinim sirven al autor para denominar al astrólogo -«maskil be-mišpeté ḥojmat ha-mazalot»-, a sus métodos y técnicas - «diné ha-mazalot»- y así también a la misma acción de la predicción astrológica-«la-din»-.

Un claro ejemplo de la importancia de la palabra mišpatim en la obra de Ibn Ezrá es que el término aparece en los títulos de dos de sus obras astrológicas. El primero es el Séfer Mišpeté ha-mazalot ('Libro de los juicios de los signos del zodíaco'), manual que instruye sobre los principios básicos de la astro-

17 Mss. Cambridge, Classmark ADD 1186, fol. 52v; Cambridge, Classmark ADD 1517 , fol. 22v. Sin embargo en el Ms. B. N. París Heb. 1056, fol. 46r no aparece el término mišpatim. 
logía. Según mis averiguaciones, se trata de su primer tratado astrológico redactado hacia el año 1146 posiblemente en la ciudad de Mantua. El libro se conserva todavía en manuscrito y es el menos conocido de la enciclopedia astrológica de nuestro autor ${ }^{18}$. En esta obra utilizó profusamente el vocablo mišpatim en claros contextos astrológicos ${ }^{19}$, y en la primera versión del Séfer Kelí ha-nehóšet ('Manual para el uso del astrolabio'), que escribió también en la ciudad de Mantua en $1146{ }^{20}$, él mismo se refirió a ella con el nombre de Séfer haMišpatim ('Libro de los juicios [de los signos del zodíaco]').

El segundo tratado astrológico en cuyo título aparece el término mišpatim es el Séfer Mišpeté ha- olam ('Libro de los juicios astrológicos del mundo'), o Séfer ha- 'Olam como generalmente se le denomina abreviadamente ${ }^{21}$. Con el nombre de Séfer Mišpeté ha- olam la conocieron varios alumnos e intérpretes de los comentarios bíblicos de Abraham ibn Ezrá que vivieron en el siglo XIV. Dos comentaristas de Abraham ibn Ezrá, los hispanojudíos José Bonfils (Yosef Tob-'Elem), que conoció muy bien su pensamiento y obra ${ }^{22}$, y Šelomó Franco, que al igual que su maestro practicó la astrología y la astronomía, se refieren a esta obra de Abraham ibn Ezrá denominándola Séfer Mišpeté ha- olam ${ }^{23}$.

${ }^{18}$ Con respecto al lugar y fecha de redacción del tratado y a la determinación de Abraham ibn Ezrá como su autor, véase la introducción de SEla Contenidos científicos. Consúltese también STEINSCHNEIDER «Geschichte» págs. 341-342; y Séfer ha-Te amim, $1^{a}$ versión, ed. I. FleISHER (Jerusalén 1951) pág. 19.

${ }^{19}$ Así lo encontramos en Mišpeté ha-mazalot, Ms. Vaticano Ebr. 477, fols. 68r, $71 \mathrm{v}-\mathrm{r}, 74 \mathrm{r}, 76 \mathrm{v}$, etc.

${ }^{20}$ Séfer Kelí ha-nehóšet, $1^{\mathrm{a}}$ versión (la denomino A) (Koenisberg 1845) págs. 25, 29 y $30-31$.

${ }^{21}$ El título Séfer Mišpeté ha- 'olam aparece explícitamente en varios manuscritos de la primera versión de la obra y en el poema que el autor o el copista solían adjuntar en el epílogo. Así sucede, por ejemplo, en el Séfer ha- 'Olam, $1^{\text {a }}$ versión (la denomino Olam A) Ms. B. N. París Heb. 1056, fol. 86r: נשלם ספר משפטי העולם / ובו נשלמו הדינים כולם

${ }^{22}$ Sobre José Bonfils y su conocimiento de la obra de Abraham ibn Ezrá, véase Uriel SIMON, «Interpreting the Interpreter: Suppercommentaries on Ibn Ezra's Commentaries», en Rabbi Abraham Ibn Ezra: Studies in the Writings of a Twelfth-Century Jewish Polymath (Cambridge 1993) págs. 119-121.

23 D. Herzog, Joseph Bonfils und sein werk Sophnath Paneah, ein bitrag zur Pentateuchexegese des Mittelalters (Heidelberg 1911) vol. I pág. 309 y vol. II pág. 27. Con respecto a Selomó Franco, vid. D. SCHWARTZ, «Abodat Elohim o abodat ha-kojabim? Ha-pulmus šel R' Abraham Altabib ve-R' Selomó Franco», Cabalá 1 (1996) págs. 223-270: pág. 258. 
Debe señalarse que la expresión mišpeté ha- olam, paralela a la latina iudicia mundi que Abraham ibn Ezrá utiliza en una obra latina, indica concisamente el objetivo central de la obra, que trata sobre la macro-astrología. En otras palabras: mišpeté ha- olam son las técnicas y los métodos astrológicos por medio de los cuales puede pronosticarse el destino colectivo de la humanidad, tanto en sus aspectos sociales, políticos o religiosos, como en lo referente a la conformación y aspecto del espacio geográfico que sirve de hábitat al ser humano.

Múltiples son las ocasiones en las que Ibn Ezrá usa el término mišpatim en sus obras científicas y es imposible analizarlas detalladamente en el marco limitado de este artículo. Por lo tanto, me contentaré con presentar las principales estructuras o paradigmas de tal uso.

En las obras científicas de Abraham ibn Ezrá, los términos mišpatim o dinim sirven de forma general para referirse a la astrología y diferenciarla de otros campos científicos cercanos, como la astronomía. Se puede encontrar un ejemplo en el Séfer ha-Te 'amim ('Libro de los fundamentos de la astrología', $1^{a}$ versión), en el pasaje donde Ibn Ezrá elogia la labor astronómica de Claudio Tolomeo, pero a la vez critica duramente su contribución astrológica, utilizando precisamente para tal objetivo los términos mišpatim y dinim:

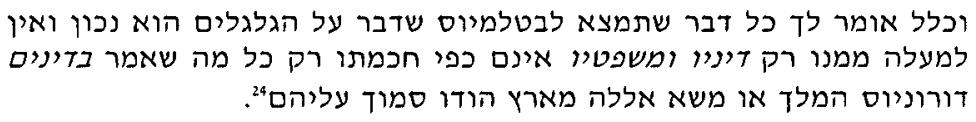

$\mathrm{Y}$ voy a darte una regla: Todo lo que encuentres de Tolomeo que trate de las órbitas [de los planetas] es correcto y nada hay más verdadero, pero sus veredictos y sus juicios [astrológicos] no corresponden a su sabiduría; sin embargo, podrás confiar en todo lo que dijeron el rey Doronio y MašáAlá de la India con respecto a los veredictos [de la astrología].

Los términos mišpatim y dinim no sólo señalan la profesión sino también a los profesionales de la astrología, y con ese objetivo Ibn Ezrá utiliza diversos giros, como hajmé mišpeté ha-

24 Séfer ha-Te amim, $1^{\mathrm{a}}$ versión (la denomino Te ámim A), Ms. B. N. París Heb. 1056 , fol. $39 \mathrm{v}$. 
mazalot ('sabios de los juicios de los signos del zodíaco') ${ }^{25}$, maskil be-mišpeté ha-mazalot ('instruido en los juicios de los signos del zodíaco') ${ }^{26}$, dayané ha-mazalot ('jueces de los signos del zodíaco') 27 o ba alé ha-mišpatim ('conocedores de los juicios astrológicos') ${ }^{28}$. Así mismo, para denominar dos subsecciones de la astrología usa expresiones como diné ha-šeelot ('veredictos de las interrogaciones') ${ }^{29}$ o diné ha-moladot ('veredictos de las natividades') ${ }^{30}$.

El término mišpatim alude también a la astrología como una metodología científica especial y diferenciada de otras. Un buen ejemplo de tal uso puede encontrarse en la introducción del Séfer Rešit hojmá, el mejor conocido de los libros astrológicos de Abraham ibn Ezrá, en cuya introducción escribe lo siguiente:

והנה אחל לפרש חקת שמים בדרך המשפטים כאשר נסו הקדמונים דור אחר

$$
\text { דור }
$$

Comenzaré a explicar las leyes de los cielos según el método de los juicios de la astrología, como lo experimentaron los antiguos generación tras generación.

Destaca en este pasaje la singular combinación que hace Ibn Ezrá del término mišpatim con la expresión hucot šamayim

${ }_{25}$ Mišpeté ha-mazalot, Ms. Vaticano Ebr. 477, fol. 71v; Séfer ha-Tbur, ed. S. Z. J. AlberShTAM (Leek 1874) pág. 6 (2).

${ }^{26}$ Séfer ha-Moladot, Ms. Cambridge, Classmark ADD 1186, fol. 52v.

27 Séfer ha-Moladot, Ms. B. N. París Heb. 1056, fol. 47v.

${ }^{28}$ Séfer ha-Te amim, $2^{\mathrm{a}}$ versión (Te amim B), ed. N. BEN MENACHEM (Jerusalén 1941) pág. 13; y Séfer ha- Tbur pág. 10 (a).

29 En el ejercicio de esa técnica debía el astrólogo contestar preguntas de carácter cotidiano, como dónde encontrar a una persona o un objeto perdido, y para eso tenía que interpretar el horóscopo del momento en que se le hacía la pregunta: Pero ello implicaba también la posibilidad del astrólogo de «leer los pensamientos» de quien presentaba la cuestión. De tal técnica astrológica se trata en las dos versiones del Séfer ha-Šeelot que redactó Abraham ibn Ezrá ( $1^{\mathrm{a}}$ versión, B. N. París Ms. Heb. 1056, fols. 62r-65r; y $2^{\mathrm{a}}$ versión, Ms. B. N. París Heb. 1058 fols. 1r-8r). Vid. también A. BouCHÉ-LECLERCQ, L'Astrologie Grecque (París 1899) págs. 458-486; y S. TESTER, A History of Western Asirology (Suffolk 1987) págs. $88-92$.

30 Séfer ha-Šelot, Ms. B. N. París Heb. 1056, fol. 62r.

31 The Beginning of Wisdom, an Astrological Treatise by Abraham Ibn Ezra, eds. Raphael LEVY y Francisco CANTERA (Baltimore 1939) pág. V (cito siempre el Rešit hojmá por esta edición). 
('leyes celestiales'), tomada del texto bíblico (Job 38:33). No debe uno asombrarse, por tanto, de encontrar la singular expresión de clara connotación astrológica mišpeté hucam ('los juicios de sus leyes') ${ }^{32}$, la cual no es más que la combinación de las dos expresiones arriba mencionadas ${ }^{33}$, en la introducción al segundo comentario de la Torá, donde Ibn Ezrá critica y se burla de los comentarios científicos de los gaones.

Con un significado fundamentalmente técnico los términos mišpatim y dinim denominan una serie de reglas, métodos o prescripciones astrológicas, formulados con simplicidad con el objetivo de pronosticar el destino particular o colectivo de la humanidad ${ }^{34}$. Abraham ibn Ezrá utiliza generalmente los términos mišpatim y dinim para referirse a diversos temas, materias o técnicas pertenecientes a la praxis astrológica. Los enumero a continuación, ejemplificando su uso en las obras de Ibn Ezrá.

1) Prescripciones astrológicas que determinan el destino mundial o colectivo, para lo cual Abraham ibn Ezrá utiliza la expresión mišpeté ha- 'olam ${ }^{35}$, o sea 'juicios del mundo'. En el

${ }^{32}$ Perušé ha-Torá le-rabenu Abraham ibn Ezrá ..., ed. A. WeISER (Jerusalén

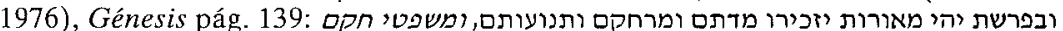
צפ 'Y en el comentario de «haya luminarias» anotaron sus dimensiones, distancias, trayectorias y los juicios de sus leyes de acuerdo a los siete climas, según experimentaron los astrólogos'.

${ }^{33}$ También en el comentario a Sal 102:27, utiliza Abraham ibn Ezrá la misma

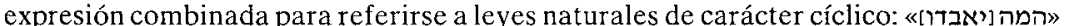
אמרו חכמי שקול הדעת כי משפט שמים וחוקותם יסורו והשם יחדש שמים חדשים וארץ חדשה "«Ellos [se acabarán]»: Han dicho los filósofos que los juicios del cielo y sus leyes se extinguirán y Dios rehará nuevos cielos y nueva tierra'.

בלל דיעין Vid. ejemplos en Rešit hojmá cap. 8 pág. LXII, donde están incluidos במולד ובתקופות ובשאלות והם מאה ועשרים, o sea 'el conjunto de los veredictos de la natividad, de los retornos cíclicos del tiempo y de las interrogaciones, que son ciento veinte'. Se encuentran también usos similares en Te 'amim A, Ms. B. N. París Heb. 1056, fols. 43-44, donde se comenta el pasaje arriba señalado de Rešit hojmá; y en Séfer ha-Meorot (en Séfer Mišpeté ha-kojabim [Jerusalén 1971]) pág.

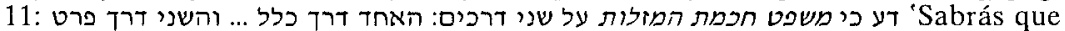
el juicio de la ciencia de los signos del zodíaco [está basado] en dos métodos: el primero [corresponde a] los acontecimientos generales ... y el segundo [a] los personales'.

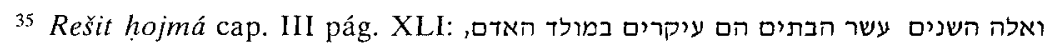
'Y esas doce casas astrológicas son de gran importancia en el horóscopo, en las interrogaciones y en las elecciones; también en los juicios del mundo, que son [los que influyen en los advenimientos] generales'. Vid. también Te amim B pág. 13; y Rešit hojmá cap. III pág. XLII. 
marco de los mišpeté ha- olam tiene fundamental importancia la referencia a las conjunciones cíclicas de Saturno y Júpiter, cuyo estudio constituye la principal técnica de la macro-astrología islámica ${ }^{36}$.

2) Las reglas que determinan los «aspectos» astrológicos y la influencia astrológica que se deriva de ellos. Los «aspectos», mabatim en hebreo, son una serie definida de distancias angulares $\left(30^{\circ}, 60^{\circ}, 90^{\circ}, 180^{\circ}\right)$ determinadas por la posición de los planetas en las casas astrológicas del horóscopo ${ }^{37}$.

3) Los dos métodos principales - la simplista «división plana» y la «división por ascensiones» que implica conocimientos astronómicos 38 - los cuales permiten determinar o calcular las doce casas astrológicas del horóscopo y su influencia astrológica ${ }^{39}$.

4) Los métodos que permiten determinar el procedimiento de «conducir en grados», le-naheg ba-máalot en hebreo o ducere ad gradus en latín ${ }^{40}$. Este procedimiento implica calcu-

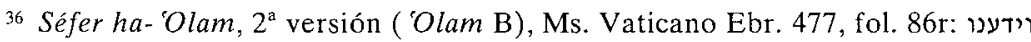

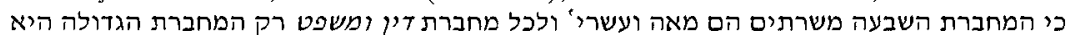
'Y sabemos que las conjunciones de los siete planetas son ciento veinte y cada una de ellas tiene su veredicto y su juicio, pero la gran conjunción, que es la de Saturno con Júpiter, es la principal y ocurre cada mil años aproximadamente' (lo mismo en 'Olam A, Ms. B. N. París Heb. 1056 , fol. $81 v$ ).

37 'Olam A, Ms. B. N. París Heb. 1056, fol. 86r: ולעולם תסתכל על המבטים, כי עליהם 'Y siempre pondrás atención en los «aspectos», porque son el fundamento de todos los juicios [astrológicos]' (lo mismo en Séfer ha-Meorot págs. 10, 13-14; Te 'amim A, Ms. B. N. París Heb. 1056, fol. 39v; y Mišpeté ha-mazalot, Ms. Vaticano Ebr. 477 , fol. $66 \mathrm{r}$ ).

38 Con respecto a esos dos métodos, vid. Shelomo SELA, «Contactos científicos entre judíos y cristianos en el siglo XII: El caso del Libro de las Tablas Astronómicas de Abraham Ibn Ezra en su versión latina y hebrea», Miscelánea de Estudios Árabes $y^{*}$ Hebraicos 45 (1996) págs. 185-222: págs. 193-195.

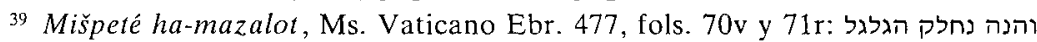

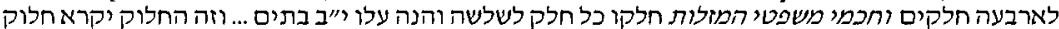
ל Y es así que el círculo se divide en cuatro partes y los sabios de los juicios de los signos del zodíaco dividieron cada parte en [otras] tres, obteniendo las doce casas [astrológicas] ... y esta división se llama plana y tiene un tercio de fuerza en los juicios de los signos del zodíaco' (lo mismo en Keli ha-nehóšet A, pág. 27).

40 Mišpeté ha-mazalot, Ms. Vaticano Ebr. 477, fol. 85v: הניהוג עיקר כל משפטי 'La conducción [en grados] es el fundamento de todos los juicios de los signos del zodíaco'. 
lar la distancia entre una «localidad de vida» y una «localidad de muerte», para poder realizar a continuación una conversión grados-años, pasando de la dimensión del espacio a la del tiempo, a consecuencia de la cual cada grado de distancia es computado como un año de vida ${ }^{41}$.

5) La influencia astrológica que proviene de las especiales trayectorias de los planetas ${ }^{42}$, y en particular de las trayectorias del sol y de la luna ${ }^{43}$.

6) Las técnicas para determinar la forma de las imágenes o la constitución física de ídolos y talismanes. Debe aclararse que esos procedimientos se refieren a la magia astral, un campo que usa técnicas y parámetros comunes con la astrología, pero que siendo de carácter netamente activo, no debe confundirse con esta, que es de índole netamente pasiva y contemplativa ${ }^{44}$.

41 Con respecto a ese procedimiento, vid. SELA «Contactos científicos» págs. 195-197. Debe señalarse que Abraham ibn Ezrá lo utiliza no sólo en sus obras científicas sino también exegéticas; véase al respecto su segundo comentario a Dan $2: 2$.

42 Así figura en el capítulo denominado Mišpeté ha-mešaretim ('Juicios astrológicos de los planetas') en Mišpeté ha-mazalot, Ms. Vaticano Ebr. 477, fol. 81 v; vid. también Séfer ha-Meorot pág. 7; y Te amim B pág. 12.

43 Te amim B pág. 27; Kelí ha-nehóšet A pág. 25; y Mišpeté ha-mazalot, Ms. Vaticano Ebr. 477 , fol. 77r.

44 Te amim B, pág. 6 וחכמי הצורות נסו ככה וככה משפט, שהם על צורות בהמה 'Y los sabios de las imágenes experimentaron esos juicios, que corresponden a formas de animales'. Vid. también Séfer ha- Ibur pág. 10 (a), donde Ibn Ezrá se refiere a una controversia científica entre los astrólogos que se basan en demostraciones matemáticas (חכמי הצורות בעלי הראיות) y los astrólogos conocedores de los juicios y de las imágenes (חכמי המזלות בעלי המשפטים והצורות). Ambas partes discuten diferentes versiones de la teoría del «trepidatio». El pasaje citado debe compararse con un fragmento del Libro de los fundamentos de las tablas, que es casi una copia textual del texto hebreo, donde los doctores ymaginum discuten también la teoría del «trepidatio» enfrentándose a los antiguos, a Hermes, a los sabios de la India y a Azarquiel. Así leemos en el Libro de los fundamentos de las Tablas Astronómicas de R. Abraham Ibn Ezra, ed. José M. Millás V AllicrosA (Madrid 1947) pág. 77: «Antiqui omnes et Hermes et indi et doctores ymaginun omnes in hoc consentiunt, quod in circulo firmamenti duo motus sunt, ascendendi in septentrionem et descendendi in austrum; inter hos tamen est aliqua discordia, nam magistri ymaginum dicunt eos motus esse polorum, indi vero duorum circulorum qui sunt in capite arietis et libre; omnes tamen in proximo dicti in hoc consentiunt quod gradus horum motuum sunt 8 , Azarchel vero asseruit 10 gradus et duas tertias gradus». 


\section{USOS DEL TÉRMINO IUDICIA EN LAS OBRAS LATINAS EN CUYA REDACCIÓN PARTICIPÓ ABRAHAM IBN EZRÁ}

Es posible enumerar por lo menos dos tratados científicos escritos en latín, en cuya redacción desempeñó Abraham ibn Ezrá un papel central. El primero de ellos es el Libro de las tablas astronómicas, al que acompañó un Libro de los fundamentos de las tablas, cuyo objetivo era explicar el uso de las tablas astronómicas y esclarecer los principios teóricos sobre los cuales se basaba su redacción. Como ya hemos visto, el distinguido estudioso de las ciencias José María Millás Vallicrosa editó una de las versiones latinas ${ }^{45}$, y por mi parte he presentado pruebas adicionales en dos artículos ${ }^{46}$ para demostrar que Abraham ibn Ezrá redactó cuatro versiones diferentes de la obra, dos en hebreo y dos en latín.

Los textos de las versiones hebreas se han perdido, pero se conservan algunos fragmentos en las obras de sus comentaristas. He tratado de demostrar que, a diferencia de las versiones hebreas, las latinas estaban dirigidas a una audiencia cristiana, aunque en sus contenidos científicos y en sus formulaciones presentan una gran afinidad con las demás obras de Abraham ibn Ezrá, tanto científicas como exegéticas y teológicas.

En dos manuscritos de la British Library se encuentran sendas copias de un manual en latín dedicado al uso del astrolabio ${ }^{47}$. M. Steinschneider fue el primero en relacionar el tratado con científicos judíos medievales ${ }^{48}$. Ya en nuestro siglo, Millás Vallicrosa, de forma similar al caso del Libro de los fundamentos de las tablas, editó el texto de esos manuscritos, y basándose exclusivamente en la evidencia interna del texto

45 Millás VAllicrosa Fundamentos.

46 SELA «Contactos científicos» págs. $185-222$ y Sh. SELA, «Puntos de contacto entre contenidos del Libro de las Tablas astronómicas en su versión latina y las obras literarias hebreas de Abraham Ibn Ezra», Miscelánea de Estudios Arabes y Hebraicos 46 (1997) págs. 37-56.

47 Tractatus de Astrolabio conscriptus disctante authori quodsam egregio pilosopho Mro. Abraham, Ms. British Library, Cotton Vesp., fols. 37-40 y British Library, Arundel 377, fols. 63-68.

${ }^{48}$ M. STEINSCHNEIDER, "Abraham Ibn Esra (Abraham Judaeus, Avenare)», Supplement zur Zeitschrift für Mathematik und Physik 25 (1880) págs. 59-128 (= Gesammelte Schriften [Berlin 1925] págs. 407-498: págs. 494-495). 
latino, atribuyó la obra a-Abraham ibn Ezrá ${ }^{49}$. Tras comparar el texto latino con las tres diferentes versiones hebreas del Séfer Kelí ha-nehóšet de Abraham ibn Ezrá que he encontrado, me inclino en la actualidad a confirmar que efectivamente nuestro autor redactó el manual latino, posiblemente con la ayuda de un alumno. Espero en un futuro cercano publicar los resultados de mi investigación y las cuatro versiones de dicho manual del astrolabio ${ }^{50}$.

Una de las características comunes a esos cuatro textos es el papel central que desempeñan las aplicaciones astrológicas y por esa razón no nos debe extrañar que el término iudicia aparezca claramente en uno de los manuscritos del manual latino del astrolabio como parte del título de un capítulo -de his qui ad iudicia pertinent- que trata de las aplicaciones astrológicas del astrolabio ${ }^{51}$. Ese capítulo y también parte de los que le siguen examinan asuntos comunes a la praxis astrológica, como el cálculo de las casas astrológicas, los aspectos planetarios y el procedimiento de «conducir en grados», es decir, todos los temas que Abraham ibn Ezrá trata también en las versiones hebreas del manual del astrolabio, usando a veces el término hebreo mišpatim ${ }^{52}$.

En su versión latina el Libro de los fundamentos de las tablas trata de temas netamente astronómicos y su principal objetivo es explicar el uso de las tablas astronómicas y los principios teóricos en los que se basa. Sin embargo, el autor también examina a lo largo y a lo ancho de la obra asuntos de

49 José María Millás Vallicrosa, «Un nuevo tratado de astrolabio de R. Abraham ibn Ezra», Al-Andalus 5 (1940) págs. 1-29. La principal evidencia para atribuir el texto a Ibn Ezrá es un fragmento donde el autor escribe: «Ut ait philosophorum sibi contemporaneorum Abraham magister noster egregius quo dictante et hanc dispositionem astrolabii conscripsimus» (Ms. British Library, Cotton Vesp., fol. 40r y British Library, Arundel 377, fol. 68r).

50 Pueden verse resultados parciales en la introducción de SELA Contenidos científicos.

51 Ms. British Library, Arundel 377, fol. 67r.

52 Ms. British Library, Arundel 377, fols. 67r-68v. Compárese Séfer Kelí ha-

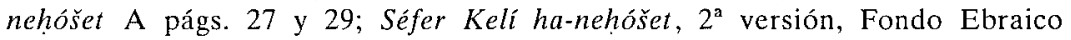

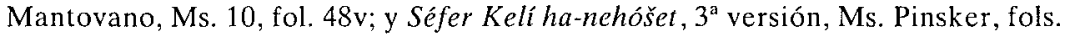
$65 r-66 v$. 
claro contenido astrológico y en esos casos emplea la palabra iudicia en expresiones y aplicaciones muy parecidas a los usos del término mišpatim que hemos encontrado en las obras hebreas de Abraham ibn Ezrá. Enumero a continución los principales giros y expresiones.

1) Empleo de la expresión doctores iudiciorum o magistri iudiciorum para denominar a los astrólogos ${ }^{53}$.

2) Uso de la expresión probatio iudiciorum para señalar el carácter netamente experimental y no matemático de la metodología astrológica ${ }^{54}$.

3) Uso de la expresión iudicia mundi -paralela a la hebrea mišpeté ha- olam- para denominar las técnicas y los métodos astrológicos por medio de los cuales se puede pronosticar el destino colectivo de la humanidad ${ }^{55}$.

4) Empleo del término iudicia y del verbo iudicare para referirse a pronósticos astrológicos relacionados con la trayectoria de la luna ${ }^{56}$.

5) Uso de la expresión iudicia ymaginum en los casos en que el término ymagines se refiere probablemente a las técnicas y

53 Millás VAllicrosa Fundamentos págs. 74 y 94.

54 Millás VAllicrosa Fundamentos págs. 83-84: «Sciendum est ergo quod partitio circuli firmamenti per 12 secundum duas sententias facta est, altera secundum cogitationem, altera secundum sensum visus est sententia; ea quidem que secundum cogitationem sententia est ea Ptholomei sententia est, que vero secundum visum est antiquorum et indorum est, et utraque harum vera est et ad artem tota admodum necessaria. Sed ea que Ptholomei est stare potest per se, altera vero sine illa nequaquam, nam sententia Ptholomei est scientia et ratio altera vero probatio iudiciorum».

55 Millás Vallicrosa Fundamentos pág. 94: «ipse idem invenit artem secundum quam observemus signum oriens in puncto adunationis solis cum luna vel oppositionis eorum proximo fere antequam sol intret in caput arietis, et inde sumantur omnia iudicia mundi». Vid. también págs. 93 y 97.

56 Millás VAllicrosa Fundamentos pág. 104: «lterum ad sciendum cum quo gradu luna sit in medio celi quod admodum necessarium est in iudiciis in ductu lune ad gradum cognitum». En ese mismo contexto, el pasaje siguiente (MILLÁs VALLiCROSA Fundamentos pág. 97) permite detectar el uso del verbo iudicare con el significado de 'realizar predicciones astrológicas': «Secundum eius adunationem cum solis vel oppositionem, iudicant magistri astronomie de omnibus eventibus mundi. Item, secundum quod ipsa est in initio infirmitatis vel cum planetis fortune vel infortunii vel eorum respectibus iudicant de creticis diebus». 
métodos mágicos que permiten a ídolos o talismanes atraer la influencia astral ${ }^{57}$.

\section{USOS DEL TÉRMINO MIŠPATIM EN LOS COMENTARIOS BÍBLICOS DE ABRAHAM IBN EZRÁ}

Dos fragmentos -el primero extraído del Libro de los fundamentos de las tablas en su versión latina y el segundo del comentario de Abraham ibn Ezrá a Sal 19:10- servirán ahora de puente entre la obra científica y exegética de nuestro autor y también de vínculo entre su obra latina y hebrea. El eslabón que une ambos fragmentos es el término mišpatim en hebreo y iudicia en latín, usados ambos con significado astrológico. He aquí los dos fragmentos en latín y en hebreo:

Item omnia iudicia astronomica secundum proportionem aliarum planetarum ad solem fiunt, secundum quod sunt orientales vel occidentales et secundum respectus eoram ad ipsum ... Item omnes doctores iudiciorum in hoc consentiunt quod ipse magister est vite, fidei, regni ${ }^{58}$.

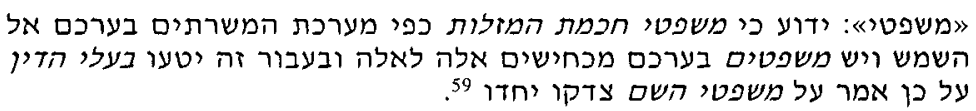

Con gran similitud los dos fragmentos tratan de las propiedades y atributos de los juicios astrológicos, los definen como dependientes de la relación entre los planetas y el sol, y otor-

\footnotetext{
57 Millás VAllicrosa Fundamentos pág. 89: «Et si vis operari in iudiciis ymaginum secundum tabulas indorum minue a medio cuiusque planete cursu eorum gradum unum, vel si in eisdem iudiciis ymaginum vis operari secundum tabulas meas minue a medio cursu cuiusque planete 8 gradus et erit anni revolucio 92 gradus et 24 minutorum. Cum volueris operari secundum astronomian vel secundum artem iudiciorum semper cum his tabulis coequa medium cursum solis, nam coequatio solis secundum has tabulas est in qua omnes magistri probationum consentiunt, tam Ptholomeum quam indos errase iudicantes. Et si vis operari in tabulis indorum in iudiciis ymaginum, ne opereris de luna».

58 Millás Vallicrosa Fundamentos págs. 73-74.

59 Comentario a Sal 19:10: " Juicios»: Es sabido que los juicios de la ciencia de los signos del zodíaco [operan] de acuerdo al sistema de los planetas en su relación con el sol, y hay juicios [basados] en estimaciones que se contradicen entre sí; y por eso se equivocan los conocedores de los veredictos [astrológicos] y por esa razón digo de los juicios de Dios que son todos ellos justos'.
} 
gan al astro rey un papel clave ${ }^{60}$. Notamos también que los términos iudicia y mišpatim se emplean con dos significados análogos. Por un lado, las expresiones latina iudicia astronomica y hebrea mišpeté hojmat ha-mazalot vienen a caracterizar la praxis astrológica, que no era sólo una faceta de carácter experimental, sino también de carácter astronómico y matemático. Por otro, las expresiones latina doctores iudiciorum y hebrea ba alé ha-din designan de forma paralela a los profesionales de la astrología.

A pesar de las obvias diferencias de léxico y de recursos literarios entre las dos lenguas, resulta asombrosa la similitud en los contenidos astrológicos de ambos fragmentos. Sin embargo, es necesario también hacer hincapié en las diferencias que los separan y para ello hay que destacar los distintos móviles que llevan a usar los juicios astrológicos en ambos fragmentos.

El del Libro de los fundamentos de las tablas pertenece al primer capítulo de la obra, en el que se tratan las propiedades astronómicas y astrológicas del sol. Ello hace que el principal motivo para introducir el término iudicia sea estrictamente técnico y se justifica por la necesidad de describir los atributos astrológicos del astro. Diferente es la situación en el comentario bíblico. A pesar de que también en este caso el término mišpatim se utiliza para describir los atributos astrológicos del sol, la razón principal de su uso es que la palabra forma parte del texto bíblico y en consecuencia Abraham ibn Ezrá, cumpliendo su función de comentarista, se propone dilucidarlo.

Pero el trasvase del término mišpatim - un concepto básicamente técnico- desde un ámbito científico a otro que es principalmente exegético, impregna al término técnico de un sentido cualitativamente teológico, lo cual ayuda a la introducción del nuevo y extraño término dentro de la esfera receptora. Así pues, de forma similar a la que antes hemos visto en la traducción de Abraham ibn Ezrá del Comentario de Ibn al-Muttana a

60 Debe señalarse al respecto que en Te amim B (pág. 27) Abraham ibn Ezrá expresa la misma idea de que los juicios de la astrología dependen de la relación entre el sol y los planetas utilizando el término hebreo mišpatim: כי מלך הכוכבים הוא השמש וכפי מרחק המשרת ממנו ישתנו המשטטים Que el rey de las estrellas es el sol, y según la distancia [a la que se encuentre] de él el planeta se modificarán los juicios [astrológicos]'. 
las Tablas astronómicas de al-Jwarizmi, en el comentario a Sal 19:10 arriba indicado la expresión mišpeté hojmat ha-mazalot, o sea 'los juicios de la ciencia de los signos del zodíaco', se usa de manera contrapuesta a la expresión mišpeté ha-Šem, o sea 'los juicios de Dios'. Por medio de esta contraposición intenta Ibn Ezrá enaltecer los juicios de Dios y al mismo tiempo reprochar a los astrólogos la imperfección de sus métodos y la inexactitud de los resultados de sus pronósticos.

Sin embargo, debe subrayarse que no hay en esa postura de Ibn Ezrá - postura que puede también observarse en sus obras científicas y exegéticas- una actitud anticientífica ${ }^{61}$. Los científicos de la Edad Antigua y de la Edad Media y también aquellos que aceptaban el valor científico de la astrología solían confesar que esta es una ciencia incompleta e imperfecta ${ }^{62}$.

Llegamos a la conclusión de que el móvil central de Ibn Ezrá es demostrar la superioridad de los juicios de Dios sobre los juicios de la astrología; de esa forma pretende afirmar que quien desee comprender profundamente el destino humano no deberá conformarse con la metodología científica estándar, es decir los juicios de la astrología, sino que deberá ampliar y completar sus conocimientos asimilando también los juicios de Dios ${ }^{63}$.

${ }^{61}$ Tanto en sus obras científicas como en sus comentarios bíblicos, Ibn Ezrá subraya la limitación del conocimiento científico y concentra sus objeciones en dos puntos principales. Por un lado, destaca la incapacidad de los matemáticos para encontrar la relación exacta entre el perímetro del círculo y su diámetro y resalta su impotencia para extraer raíces cuadradas exactas; vid. al respecto Moritz Silberberg, Séfer Ha-Mispar, Das Buch der Zahl: Ein hebräisch-aritmetisches Werl des R. Abraham ibn Esra, Zum ersten Male herausgegeben ins Deutsche übersetzt und erläutert (Frankfurt 1895) cap. 5 págs. 44-45; el comentario corto de Abraham ibn Ezrá a Éx 23-20; y Millás VAlliCROSA Fundamentos pág. 124. Por otro lado, subraya Abraham ibn Ezrá la inexactitud de lás predicciones astrológicas y de los diagnósticos médicos, y así se encuentra en Te amim B pág. 2 y en Séfer ha-Moladot, Ms. B. N. Paris Heb. 1056, fol. 46r.

62 Ptolomeo, Tetrabiblos, ed. F. E. Robiins (Londres 1980) págs. 2-19. Vid. también la opinión de Abraham bar Hiyá, el colega de Ibn Ezrá, sobre la limitada eficacia de la astrología y su relación con la astronomía en Séfer Șurat ha-areș (Basilea 1546) págs. 4-6.

${ }^{63}$ Este es un punto fundamental del pensamiento de Abraham ibn Ezrá que me es imposible desarrollar en el presente artículo. Se puede decir brevemente que el autor afirma que el conocimiento de los juicios divinos está supeditado a la 
Un buen signo de la introducción y de la fusión armónica del término mišpatim en el nuevo medio exegético-teológico puede encontrarse en el uso de la expresión con resonancias astrológicas mišpeté ha-Šem 'juicios de Dios' en varios contextos que enumero a continuación.

1) Interpretación astrológica del curso de la historia, especialmente de la de las naciones y de las religiones, por medio de la observación de las conjunciones de Saturno y Júpiter. Así, en su comentario a las palabras «se echó pur ('suerte')» de Est 3:7, escribe Ibn Ezrá que «han dicho otros que se debió a las conjunciones de los planetas superiores [Saturno y Júpiter] en el signo de Capricornio, el cual está alejado 12 signos de Acuario que es el signo astrológico de Israel, y lo cierto es que así se echó a suertes, porque los juicios provienen de Dios y Dios prolongó el tiempo para que los judíos se arrepintieran y se salvaran».

2) Influencia estelar sobre el clima, entendida como parte integral de la predicción astrológica. Un ejemplo es el comentario de Abraham ibn Ezrá a la palabra juicios en Sal 147:19: «Esta escrito "sus leyes y juicios" porque ellos son la causa de la lluvia».

3) Entender el término mišpatim como una consecuencia de la actuación de los ángeles que, según la concepción de Ibn Ezrá, son los mismos astros o representan las leyes de la naturaleza. Un ejemplo puede encontrarse en su comentario a Sal 82:1: “En medio de Elohim": los ángeles son Elohim y el ejército del cielo son los hijos de Elohim, porque por medio de los ángeles se expide todo juicio de Elohim en la tierra».

4) La concepción de los mišpatim como una revelación de pronósticos quasi astrológicos que radican en los veredictos divinos y que se pueden averiguar interrogando a los Urim y Tumim. Y así en su comentario a la expresión «Hošen mišpat

revelación de los contenidos secretos encerrados en los valores numéricos de las letras de los nombres de Dios, lo cual implica el conocimiento de las ciencias matemáticas y especialmente de la combinación de los valores numéricos de las letras del alefato. Vid. respectivamente los comentarios largos a $E_{x}$ 3:15 y $33: 21$ y el comentario corto a Éx 3:13; cf. Séfer ha-Šem y Séfer Yesod mor ä en Yalcut Abraham Ibn Ezrá, ed. Israel LeviN (New York-Tel Aviv 1985) págs. 419-428 y cap. 11 pág. 339. 
Urim ve-Tumin» (Éx 28:30) escribe Ibn Ezrá: «Y el significado del juicio son los veredictos divinos futuros, y por eso se interroga a los Urim y Tumin» ${ }^{64}$.

\section{LOS JUICIOS DE LA ASTROLOGÍA, LAS ANTIGUAS CIENCIAS DE ISRAEL Y EL SIGNIFICADO DE LOS MANDAMIENTOS DE LA RELIGIÓN JUDÍA}

En el contexto cultural en que vivió Abraham ibn Ezrá la astrología y la astronomía pertenecen a la categoría de ciencias externas o ciencias foráneas, según él mismo expresa en varias ocasiones ${ }^{65}$. La incorporación del estudio de las ciencias a un medio cultural conservador y estrecho de miras solía despertar resistencia y desagrado. Para paliar o moderar tal situación y para legitimar sus aspiraciones científicas, intelectuales judíos del siglo XII sostienen que sus actividades no son más que la restauración de un prístino siglo de oro, en el que los antiguos sabios de Israel desempeñaron actividades científicas a un nivel igual o superior al que desplegaron los sabios gentiles ${ }^{66}$.

Un ejemplo de ello es la opinión de que en el antiguo Israel actuaron dos escuelas científicas, creencia que se desarrolló entre intelectuales judíos procedentes de Al-Ándalus. Ambas escuelas se concentraron en el estudio de la astronomía con el objeto de solucionar los problemas del calendario hebreo, especialmente en lo que se refiere a su relación con el ciclo anual solar. Las fuentes nos relatan que el principal objetivo de esos intelectuales era averiguar la medida exacta de la llamada tecufá, o sea, el momento preciso en que el sol entraba en el signo de Aries, lo cual marcaba el fin de un año solar y el comienzo de otro.

\footnotetext{
${ }^{64}$ Vid. también el comentario corto a $\dot{E} x$ 28:4.

${ }^{65}$ Vid. el comentario largo a Dan 10:21; GoLDSTEIN Ibn al-Muthannâ (versión Parma) pág. 302 ; introducción al comentario largo y corto a la Torá; y comentarios a Is $47: 12$ y $55: 12$.

${ }^{66}$ Se desarrolla así el mito de que los sabios griegos «robaron» las ciencias a los sabios de Israel. Sobre el desarrollo del mito desde la Edad Antigua hasta la Edad Media véase N. ROTH «The 'Theft of Philosophy' by the Greeks from the Jews», Classical Folia 32 (1978) págs. 53-67. Véase también Séfer ha- Ibur de Abraham bar Hiyá, ed. H. FILIPOWSKY (Londres 1851) págs. 37-38; y Séfer ha-Cuzarí de Yehudá Haleví, ed. Yehuda Ibn Shmuel (Tel Aviv 1972) parte II, cap. 66 pág. 85. Y asimismo Maimónides, Hiljot quidúš ha-hodeš, caps. 17 y 24, quien no participa de la teoría del «hurto» de las ciencias.
} 
La primera escuela, dirigida por rab Šemuel, actuó públicamente y se la consideró de bajo nivel, ya que se conformó con soluciones simples, aproximadas e inexactas. La segunda, encabezada por rab Ada, logró resultados científicos sumamente exactos; pero esta escuela actuó reservadamente, casi de forma oculta y guardó sus descubrimientos en secreto ${ }^{67}$.

Abraham ibn Ezrá, que recibió y transmitió esa tradición, tiene una opinión muy especial sobre la razón por la cual la escuela de rab Ada actuaba casi en la clandestinidad. En su obra Iguéret ha-šabat ('Epístola del sábado') escribe: «La tecufá, según la escuela de rab Šemuel, era pública y abierta a todo el mundo y la razón por la cual la tecufá según la escuela de rab Ada se guardaba en secreto estribaba en los juicios de los signos del zodíaco [mišpeté ha-mazalot]» 68. Abraham ibn Ezrá agrega nuevos datos en su Séfer ha- Ibur, donde escribe:

ובעבור שאמרו קדמונינו זיל שתקופת רב אדא בצנעא פירשו בו חכמי הדור

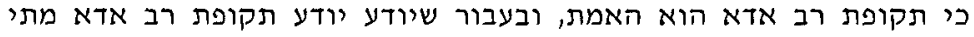

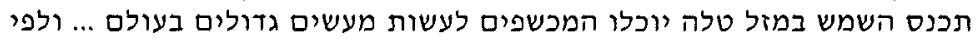
דעתי שהיתה בצנעא בעיל משור שיוכלוכל לדעת איש כל אשר יהיה בארץ בדרד

$$
\text { חכמי משפטי המזלות בצנית בעירות. }
$$

$\mathrm{Y}$ a causa de que nuestros antepasados, su recuerdo sea bendito, dijeron que la tecufá según rab Ada se guardaba en secreto, interpretaron sus contemporáneos que la tecufá según rab Ada era la verdadera, y dado que quien conoce la tecufá según rab Ada sabe cuándo entrará el sol en el signo de Aries, podrían [así] los magos realizar grandes obras en el mundo ... Pero en mi opinión [la tecufá según rab Ada] se guardaba en secreto porque cualquiera podría saber todo lo que iba a ocurrir en la tierra según los métodos de los sabios de los juicios de los signos del zodíaco.

Resulta entonces que tanto en la Iguéret ha-šabat como en el Séfer ha- Ibur afirma Abraham ibn Ezrá que la tecufá según rab Ada se guardaba en secreto porque operaba según los

\footnotetext{
${ }^{67}$ Abraham bar Hiyá, Séfer ha- Ibur pág. 81; Yehudá Haleví, Séfer ha-Cuzarí, parte IV, cap. 28 pág. 190; y Maimónides Hiljot quidúš ha-hodeš cap. 9, 1.

${ }^{68}$ Iguéret ha-šabat, ed. M. FRIEDLANDER en Transactions of the Jewish Historical Society of England 2 (1894-1895) págs. 61-75: pág. 66.

${ }^{69}$ Séfer ha- Tlbur pág. 6 b.
} 
métodos de los sabios de los juicios de los signos del zodíaco; está claro que esos métodos rebasaban el limitado campo de la astronomía, necesaria para fijar el calendario de la religión judía. Se señalan al respecto dos hechos principales: por un lado, los juicios de los signos del zodíaco permitían «saber todo lo que iba a ocurrir en la tierra», o sea, realizar predicciones astrológicas mundiales; por otro, Abraham ibn Ezrá nos dice que los juicios de los signos del zodíaco los utilizaban los magos para realizar grandes obras en el mundo, o sea, que comprendían la magia mundial ${ }^{70}$.

En la introducción del Séfer Yesod mor'a subraya Ibn Ezrá que el intelectual judío no debe conformarse con estudios de exclusivo carácter judío, ya que para entender cabalmente los interrogantes que surgen de la lectura del Talmud y de la Torá son necesarias las demás ciencias, o sea las ciencias externas o ciencias foráneas. Presenta Ibn Ezrá un programa de estudios básicos que comprende la mayoría de las ciencias conocidas en su época: astronomía, astrología, geometría, sicología, lógica y gramática. Agrega también los juicios de los signos del zodíaco y sucintamente explica que en su opinión estos son necesarios para entender «el asunto de Agrat bat Mahlat» ${ }^{71}$.

Leyendo su comentario largo a $E x$ 20:13, donde resume su opinión sobre el significado y el sentido de los diez mandamientos, podemos comprender por qué en el Séfer Yesod mor'á recomendaba el estudio de los juicios de los signos del zodíaco. Se trata de un comentario audaz en el cual Abraham ibn Ezrá no titubea en vincular directamente la influencia astrológica de Saturno con el mandamiento que ordena guardar la santidad del sábado:

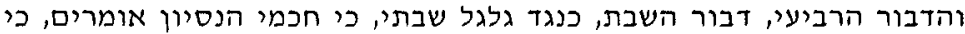

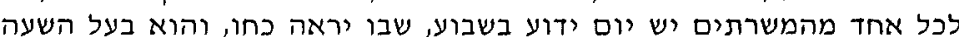

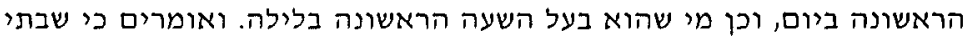

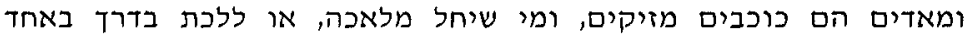

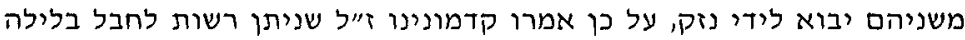

70 También Abraham bar Hiyá tenía una opinión similar; vid. su Séfer ha- Ifour pág. 94. Abraham ibn Ezrá subraya en sus comentarios bíblicos esa relación entre mišpatim y la magia, como por ejemplo en su explicación de la palabra quesamim de Deut 18:10, donde escribe: «y su significado son operaciones mágicas que hay en los juicios de las estrellas».

${ }^{71}$ Séfer Yesod mor'á págs. 318-319. 
רביעיות ובלילה שבתות. והנה לא תמצא בכל ימי השבוע לילה ויוּם זה אחר

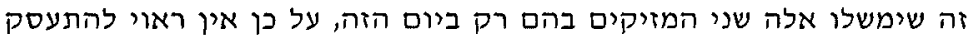

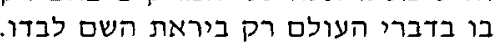

EI cuarto mandamiento, el mandamiento del sábado, está en relación con la esfera de Saturno, ya que los astrólogos dicen que cada uno de los planetas gobierna un determinado día de la semana en el cual se hace patente su poder, y ese planeta gobierna la primera hora del día y otro gobierna la primera hora de la noche. Dicen también que Saturno y Marte son dos estrellas destructivas y aquel que comienze una faena o emprende un viaje bajo alguno de ellos se verá perjudicado. Por eso han dicho nuestros antepasados, bendita sea su memoria, que se dió permiso para causar daño la noche de los miércoles y la noche de los sábados. Y he aquí que no encontrarás en todos los días de la semana una noche y un día consecutivos que estén dominados por esos planetas dañinos salvo ese día [el sábado], por eso no hay que ocuparse en él de tareas profanas sino sólamente en el temor de Dios.

Se trata, pues, de un vínculo extremadamente problemático, ya que la astrología que Abraham ibn Ezrá conoció otorgaba a Saturno tres atributos fundamentales: a) cada uno de los siete planetas gobierna un día de la semana y justamente Saturno es el encargado del sábado ${ }^{72}$; b) de acuerdo con los preceptos de la astrología mundial, los planetas se ocupan del destino de los diferentes pueblos y naciones, y justamente Saturno gobierna al pueblo judío ${ }^{73}$; y c) en el marco de los siete planetas conocidos en la antigüedad y en la Edad Media, se considera a Saturno como aquel que posee los atributos astrológicos más negativos ${ }^{74}$.

${ }^{72}$ Rešit hojmá cap. 4 pág. XLIV; y Te ámim A, Ms. B. N. París Heb. 1056, fol. $41 \mathrm{v}$.

73 Albumasar, De magnis conjunctionibus, annorum revolutionibus ac eorum profectionibus, traducción de Johannes HISPALENSIS (Augsburg 1489) pág. a 7r; Rešit hojmá cap. 4 pág. XLII; y Te amim A, Ms. B. N. París Heb. 1056, fol. 41v.

${ }^{74}$ En Rešit hojmá cap. 4 pág. XLII, Abraham ibn Ezrá escribe que Saturno es «maligno, dañino, destructivo, ordena la muerte, la tristeza, el duelo, el llanto y los gemidos». En Téamim A (Ms. B. N. París Heb. 1056, fol. 41v) dice que Saturno «es frío, seco, y el principio de la muerte es frío y sequedad, por lo tanto Saturno ordena la muerte, la tristeza y el sufrimiento»; y también en Te amim B pág. 25, que Saturno es «el ángel de la muerte y la oposición a la vida». 
La problemática relación entre Saturno, el sábado y los judíos ya se conocía en la antigüedad y en la civilización árabe ${ }^{75}$. Sin desmentir tal opinión, Abraham ibn Ezrá trata de convertirla en una ventaja que favorece la práctica de la religión judía. Con ese objetivo hace alusión a una tradición legendaria talmúdica según la cual se alerta a quien desee salir las noches del sábado y del miércoles que Agrat bat Mahlat junto a 18.000 ángeles destructivos está autorizada esos días para causar daño ${ }^{76}$. En su comentario a Éx 20:13 muestra Abraham ibn Ezrá la utilidad de los juicios de la astrología para entender esa tradición talmúdica; de su explicación se deduce que Agrat bat Mahlat no es más que la personificación del destructivo Saturno. Se llega a la conclusión de que el cuarto mandamiento ordena el descanso sabático para evitar los daños que puede causar Saturno, de la misma manera que la tradición talmúdica aconseja no salir los sábados para evitar la acción destructiva de Agrat bat Mahlat.

\section{LA DIFUSIÓN DE LOS JUICIOS DE LA ASTROLOGÍA EN LA SO- CIEDAD LATINO-CRISTIANA DESPUÉS DE LA MUERTE DE ABRAHAM IBN EZRÁ}

Según hemos visto, Abraham ibn Ezrá contribuyó ya en vida a introducir los juicios de la astrología en la lengua latina. Veremos ahora cómo eso fue sólo el comienzo, ya que después de su muerte se tradujeron varias de sus obras y se divulgaron dentro de la sociedad latino-cristiana ${ }^{77}$, y así también el

\footnotetext{
75 Así en TÁCITo, Historiae V 4, leemos: «septimo die, otium placuisse ferunt, quia is finem laborum tulerit ... a lii honorem eum Saturno haberi, seu principia religionis tradentibus Idaeis, quos cum Saturno pulsos et conditores gentis accepimus, seu quod de septem sideribus, quis mortales reguntur, altissimo orbe et praecipua potentia stella Saturni feratur, se pleraque caelestium viam suam et cursus septenos per numeros commeare». E igualmente explícitas son las palabras de los científicos árabes: «¿No dicen los judíos que son "saturnales"? La cosa es indudable, pues, de hecho, ¿no hacen fiesta el sábado, que es el día de Saturno, y no está su carácter del todo acomodado a las cualidades de que es indicio Saturno, o sea, avaricia, sordidez, ruindad, engaño y traición?»; vid. El siglo XI en $1^{a}$ persona: Las «Memorias» de 'Abd Allah, último rey Zirí de Granada, destronado por los alomorávides (1090), ed. E. LeVí ProvenÇAL y Emilio GarCía Gómez (Madrid 1980) pág. 315.

76 TB-Pesahim 112a.

77 R. LEVY, The Astrological Works of Abraham Ibn Ezra (Baltimore 1927) págs. 19-57.
} 
término mišpatim, acompañado de su significado astrológico, pasó a la lengua latina y a las lenguas romances modernas, que estaban entonces en pleno proceso de formación.

Me ocuparé en este apartado sólo de la primera etapa de la traducción y divulgación del pensamiento de Abraham ibn Ezrá en la cultura latina, etapa en la que puede observarse cómo el término mišpatim pasa a la lengua francesa y al latín.

En el año 1273, o sea casi cien años después de la muerte de Ibn Ezrá, Enrique Bat emprendía en París la labor de traducir tratados hebreos al francés, entre los cuales se encuentran dos obras astrológicas de nuestro autor ${ }^{78}$.

La traducción más importante fue la del Séfer Rešit hojmá, cuyo título en latín es Introductorius ad astronomiam: Initium sapientiae, labor que Enrique Bat realizó con la ayuda de un judío llamado Hagin. Últimamente esta traducción ha despertado interés, no tanto por sus contenidos astrológicos como por constituir una de las primeras obras redactadas en francés y por tanto una excelente muestra para estudiar las primeras etapas de la cristalización de esa lengua.

En el texto de dicha traducción hace su aparición la palabra jugements con un claro significado astrológico y como traducción directa del término hebreo mišpatim. Ello puede observarse claramente en un fragmento de la introducción del Séfer Rešit hojmá, del cual presentamos a continuación el texto hebreo y su versión francesa:

והנה אחל לפרש חקת שמים בדרך המשפטים כאשר נסו הקדמונים דור אחר

$$
\text { דור }
$$

Et je commencerai a retraire la costume des cieus en la voie des jugements que ont essaié les anciens generacion uns aprés autre ${ }^{80}$.

\footnotetext{
${ }^{78}$ Sobre la contribución científica de Enrique Bat y las traducciones que promovió, vid. LEvy Astrological págs. 19-32. En esas traducciones, que no son las únicas de su tiempo, puede verse una muestra del gran interés que tuvieron los intelectuales cristianos por conocer las obras de los astrólogos judíos. Debe observarse al respecto que en la residencia de Enrique Bat se tradujo también al francés y al latín la obra de Abraham bar Hiyá, Meguilat ha-megalé, que incluye un capítulo entero en el que aparece una explicación astrológica de la historia mundial (vid. ed. POZNANSKY págs. XXVIII y XXXV).

79 Rešit hojmá pág. V; vid. la traducción española supra y nota 31.

${ }^{80}$ Introductorius pág. 31.
} 
En la residencia de Enrique Bat se realizaron también traducciones al latín de otras obras astrológicas de Ibn Ezrá, entre las que se cuenta el Séfer ha-Téamim, que en latín se denominó Liber rationum de causis et revolutionibus que dicuntur in introductione ad iudicia astrorum, título en el que la expresión hebrea mišpeté ha-mazalot se traduce en latín por iudicia astrorum ${ }^{81}$.

Otra obra traducida es el Séfer ha-Moladot, denominado en latín Liber Abraham Iudei de nativitatibus e impreso en Venecia en el año 1485 junto con un manual del astrolabio escrito por el propio Bat ${ }^{82}$. Los contenidos y la terminología especial de la obra revelan que Abraham ibn Ezrá fue su autor, pero en algunas partes el texto de la traducción es significativamente diferente del texto hebreo del Séfer ha-Moladot. Ello nos hace concluir que el Liber Abraham Iudei de nativitatibus es la traducción latina de una segunda versión del Séfer haMoladot, diferente de la primera no sólo en sus contenidos sino también en su fecha de redacción. Mientras que la primera versión del Séfer ha-Moladot se redactó en 1148, la segunda lo fue en el año 1154 o posteriormente ${ }^{83}$. En numerosas ocasiones aparecen en el texto latino el substantivo iudicia y el verbo iudicare con claro significado astrológico, correspondiendo al sustantivo hebreo mišpatim y al verbo la-din arriba señalados. Como ejemplo aduzco un fragmento que describe el papel que cumple Saturno en la novena casa astrológica con respecto a la fe religiosa de un judío y un cristiano:

${ }^{81}$ En la residencia de Enrique Bat se tradujeron otros dos tratados astrológicos de Abraham ibn Ezrá: a) el Séfer ha- Olam, cuyo título en latín es Liber conjunctionum planetarum et revolutionum annorum mundi qui dicitur de mundo ver seculo; y b) el Séfer ha-Meorot, traducido como Tractatus de luminaribus et diebus creticus (vid. LEVY Astrological págs. 28-29). Sobre las traducciones latinas del Séfer ha-Te 'amim vid. J. HALBRONN, «Le diptyque astrologique d'Abraham Ibn Ezra et les cycles planétaires du Liber Rationum», REJ 155 (1996) págs. 171-184.

82 Liber Abraham Iude de Nativitatibus et Compositio Astrolabii Henrici Bate (Venetia 1485).

${ }^{83}$ Sobre esas dos diferentes versiones véase la introducción de SEla Contenidos científicos. Con respecto a la fecha de redacción de la segunda, véase Liber Abraham Iude de nativitatibus (Venetia 1485) pág. c 2v: «Hoc anno 1154 ab incarnatione domini est adunatio eorum in triplicitate terrae ... nunc autem 122 anni sunt ex quo inceperunt adunationes in hoc triplicitate fieri, restat aut adhuc 113 post quas continuabunt adunationes». 
Notandum quod hanc domum de fidei religione et scientia iudicare ... Saturnus in nona nativitate iudei suam fidem constant ostendit, christianus nativitate suam fidem neglucturus $i u$ dicat ${ }^{84}$.

\section{PRIMERA ETAPA EN LA DIFUSIÓN DEL TÉRMINO ASTROLÓGI- CO MIŚPATIM EN EL HEBREO MEDIEVAL DESPUÉS DE LA MUERTE DE ABRAHAM IBN EZRÁ}

En este apartado sólo voy a señalar dos casos que no rebasan la mitad del siglo XIII, cada uno de los cuales pertenece a un género literario diferente y en los que puede advertirse claramente la influencia de Abraham ibn Ezrá.

El primero revela un vínculo hasta ahora desconocido entre Maimónides e Ibn Ezrá. Maimónides se opuso abiertamente a la práctica de la astrología, especialmente por motivos religiosos. Posiblemente esa fue una de las razones por las que ignoró completamente a Ibn Ezrá, quien estaba a favor de la astrología y la usó no solo en sus tratados científicos sino también en un lugar tan fundamental para la praxis religiosa como son los comentarios bíblicos. Deseo mostrar a continuación que, a pesar de ese divorcio entre Maimónides y Abraham ibn Ezrá, una de las primeras manifestaciones de los juicios astrológi$\cos$ en la lengua hebrea, concepto creado directamente por Abraham ibn Ezrá, llegó justamente a manos de Maimónides.

Hacia 1190 un grupo de rabinos provenzales envió a Maimónides una epístola que trataba sobre diferentes temas de astrología. La carta se hizo famosa por la respuesta de este, en la cual niega rotundamente la validez práctica y religiosa de la astrología ${ }^{85}$. De mi estudio del texto he llegado a la conclusión

${ }^{84}$ De nativitatibus pág. c $2 \mathrm{v}$. Compárese el fragmento siguiente de la primera versión del Séfer ha-Moladot, Ms. B. N. París Heb. 1056, fol. 46r

85 Vid. el texto de la epístola y la respuesta de Maimónides en A. MARX, The Correspondence between the Rabbis of Southern France and Maimónides about Astrology (New York 1926). Con respecto a la respuesta de Maimónides vid. R. BARKAI, «L'astrologie juive médiévale: Aspects théoriques et pratiques», Le Moyen Âge 93 (1967) págs. 323-348; T. LANGERMANN, «Maimonide's Repudiation of Astrology», Maimonidean Studies 2 (1991) págs. 123-158: págs. 124-123; G. Freudenthal, «Maimonides' Stance on Astrology in Context: Cosmology, Physics, Medicine, and Providence», en Moses Maimonides, Physician, Scientist, 
de que, sin revelar el nombre del autor, los rabinos provenzales copiaron literalmente fragmentos enteros de las obras astrológicas de Abraham ibn Ezrá y usaron el término astrológico mišpatim y otros giros derivados.

A modo de ejemplo, veamos los siguientes dos fragmentos procedentes el primero de la epístola en la que los rabinos provenzales requieren la opinión de Maimónides sobre las «interrogaciones» astrológicas ${ }^{86}$ y el segundo de la primera versión del Séfer ha-Šeelot en los que aparecen términos como mišpatim, dinim y la-din (subrayo los pasajes paralelos):

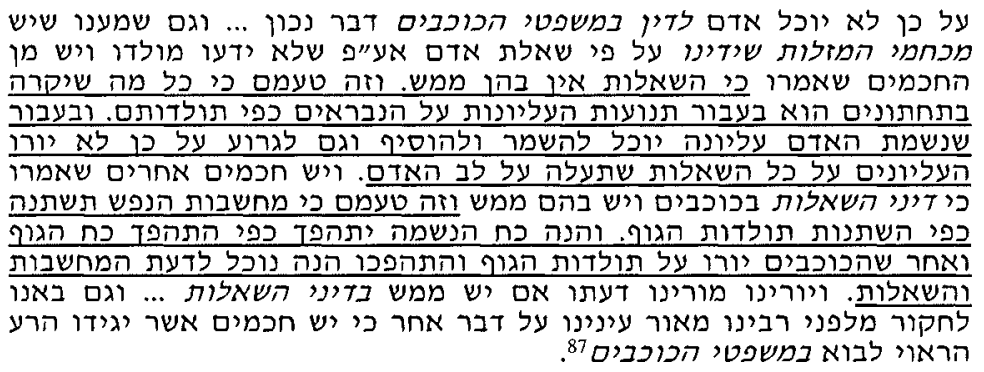

and Philosopher (London 1993) págs. 77-90; y H. KREISEL, «Maimonides' Approach to Astrology» [en hebreo], en Proceedings of the Eleventh World Congress of Jewish Studies (Jerusalem 1994) Division C, vol. II págs. 25-32.

86 Sobre esta técnica astrológica vid. supra nota 29.

87 MARX Correspondence pág. 40: 'Por lo tanto, nadie podrá dar veredicto verdadero en los juicios de las estrellas ... y también hemos oído que hay algunos astrólogos que dan veredicto según la pregunta de alguien aunque no conocen su horóscopo, y hay otros sabios que han dicho que el método de las interrogaciones no es verdadero. Y la razón es que todo lo que acontece a los cuerpos inferiores se debe a los movimientos de los cuerpos superiores y a sus naturalezas. Por estar dotado de un alma superior, el ser humano puede guardarse [de los daños procedentes de las estrellas] y agregar o disminuir [los desastres de su destino]. Por tanto los cuerpos superiores no pueden dar respuesta a todas las interrogaciones que se suscitan en el corazón humano. Hay otros sabios que sostienen que los veredictos de las interrogaciones son ciertos, y la razón que exponen es que los pensamientos del alma se modifican según los cambios del devenir corporal, y la fuerza del espíritu se altera según a las alteraciones de la fuerza del cuerpo. Y teniendo en cuenta que las estrellas gobiernan la evolución del cuerpo y sus trasformaciones, he aquí que podemos conocer los pensamientos [del hombre] y sus interrogaciones. Que nuestro maestro nos dé su opinión sobre si hay algo de cierto en los veredictos de las interrogaciones ... y también venimos a averiguar de nuestro rabí, luz de nuestros ojos, sobre lo que dicen algunos sabios acerca de las calamidades que deben acontecer de acuerdo a los juicios de las estrellas'. 


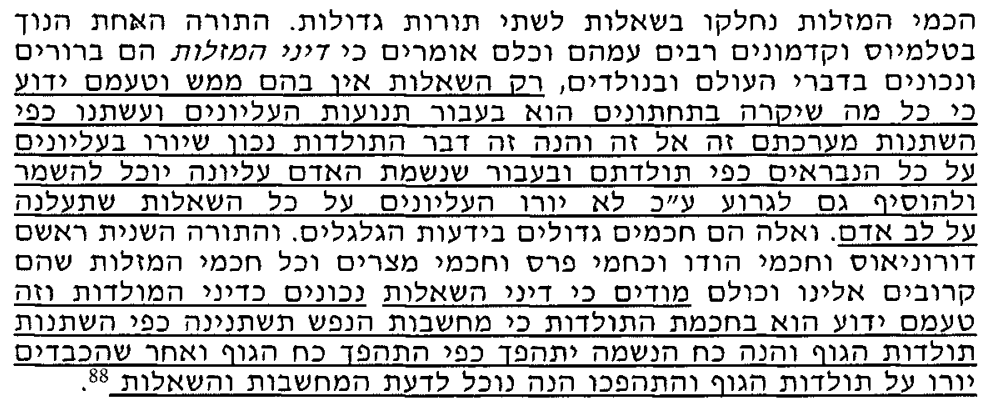

Las huellas de Abraham ibn Ezrá pueden también rastrearse en el género literario del comentario bíblico, en el que el término mišpatim se asimila a sus concepciones científicas, exegéticas y teológicas. Voy a limitarme a la producción literaria de la familia Quimhí, en la cual puede palparse claramente la influencia de Abraham ibn Ezrá.

Un ejemplo es el comentario que dedicó Mošé Quimhí (-1190) a la palabra quésem ('magia') de Prov 16:10. En su comentario utiliza la expresión mišpat ha-kojabim y al mismo tiempo repite la opinión que Ibn Ezrá expresaba en su comentario a Deut $18: 10^{89}$.

88 Séfer ha-Šeelot, Ms. B. N. París Heb. 1056, fol. 62r: 'Los astrólogos se dividen en dos doctrinas diferentes con respecto a las interrogaciones. A la primera se apegan Enok, Tolomeo y muchos de los antiguos. Todos ellos sostienen que los veredictos de los signos del zodíaco son claros y correctos en los asuntos mundiales y personales, pero las interrogaciones no son ciertas, y la razón es que todo lo que acontece a los cuerpos inferiores se debe a los movimientos de los cuerpos superiores y a los cambios entre sus relativas posiciones. Y también la naturaleza de los cuerpos inferiores creados está gobernada por la naturaleza de los superiores. Por estar dotado de un alma superior, el ser humano puede guardarse [de los daños que provienen de las estrellas] y agregar o disminuir [los desastres de su destino]. Por tanto los cuerpos superiores no indican todas las interrogaciones que se suscitan en el corazón del hombre. Estos son grandes sabios en la astronomía. Encabeza la segunda doctrina Doronio y los sabios de la India, Persia y Egipto y todos los astrólogos que nos son cercanos; todos ellos confiesan que los veredictos de las interrogaciones son tan ciertos como los veredictos de las natividades, y la razón que exponen es que en la astrología los pensamientos del alma se modifican según la evolución del cuerpo, y he aquí que la fuerza del espíritu se altera según las alteraciones de la fuerza del cuerpo. Teniendo en cuenta que las estrellas gobiernan la evolución del cuerpo y sus alteraciones, podemos conocer los pensamientos [del hombre] y sus interrogaciones'.

${ }^{89}$ La similitud de los dos comentarios hizo que el de Quimhí se atribuyera erroneamente a Abraham ibn Ezrá; vid. al respecto E. TALMAGE, «Paršané Provans ba-meá ha-XII u-ber'ešit ha-meá ha-XIII», en Paršanut ha-Micrá hayehudit, ed. M. GRINBERG (Jerusalén 1983) págs. 87-88. 
También David Quimhí (1160-1235), más famoso que su hermano Mošé, suele repetir las opiniones de Ibn Ezrá y en dos ocasiones no sólo revela su fuente de inspiración sino que también utiliza la expresión mišpat ha-mazalot. En el comentario a 1 Sam 19:9 identifica los terafim con el astrolabio o con ídolos dotados de forma humana, pero admite abiertamente que esa opinión la toma del comentario de Ibn Ezrá a Gén $31: 19{ }^{90}$ y utiliza su expresión mišpat ha-mazalot ${ }^{91}$. El segundo ejemplo es similar al primero; en su comentario a $I s$ 44:25 también repite el comentario de Ibn Ezrá a ese versículo y hace uso de la expresión mišpat ha-mazalot ${ }^{92}$.

\section{CONCLUSIÓN}

Según ya he adelantado, la creación del término mišpatim con significado astrológico debe entenderse como un caso particular de un fenómeno general: la creación de un léxico científico hebreo basado explícita y conscientemente en el vocabulario bíblico. Pero en la mayoría de los casos las innovaciones lingüísticas de Abraham ibn Ezrá en la lengua hebrea -térmi-

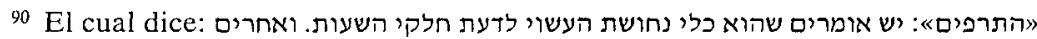

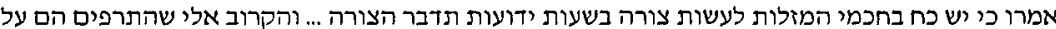
"Terafim»: Hay quienes dicen que es el astrolabio que está hecho para conocer las partes de las horas. Otros han dicho que los astrólogos tienen el poder de fabricar imágenes y en determinadas horas la ìmagen habla ... en mi opinión los terafim tienen forma humana y están hechos para poder recibir fuerza de las entidades superiores, pero no puedo explicar más'.

ועני" התרפים:... Micraot Guedolotha-Quéter (Ramat Gan 1993), Samuel pág. 101

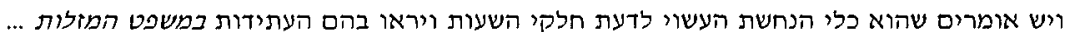

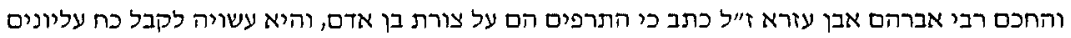
'Con respecto al asunto de los terafim: ... hay quienes dicen que es el astrolabio, que está hecho para conocer las partes de las horas y para poder predecir el futuro de acuerdo a los juicios de los signos del zodíaco ... y el sabio rabí Abraham ibn Ezrá, su recuerdo sea bendito, ha escrito [Gén 31:19] que los terafim tienen forma humana y están hechos para poder recibir fuerza de las entidades superiores'.

92 Micraot Guedolot ha-Quéter (Ramat Gan 1996), Samuel pág. 293: וקראם בדים

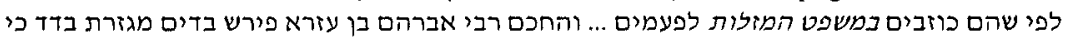

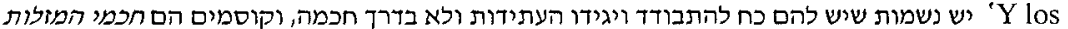
llamó badim porque son a veces falsos en los juicios de los signos del zodiaco ... y el sabio rabí Abraham ibn Ezrá explicó que el término badim proviene de badad, ya que hay espíritus que tiene el poder de aislarse y de predecir el futuro pero no de acuerdo a la sabiduría, y los magos [cosemim] son los astrólogos'. 
nos como musac que tomó de Job 36:16, o la expresión nahaš baríah según $J o b$ 26:13- fueron efímeras y desaparecieron con su muerte. Diferente suerte corrió el término mišpatim, cuyo uso prosperó y se difundió después de la muerte de nuestro autor. No debe olvidarse que la concepción científica tolomeica que recibió el Occidente latino y también la sociedad judía contenía no sólo aspectos astronómicos sino también otros plenamente astrológicos. El éxito en la divulgación del término mišpatim debe atribuirse al hecho fundamental de que reflejaba fielmente uno de los aspectos más centrales y vitales de esa concepción científica del mundo. Pero en grado no menor la propagación del término debe también atribuirse a la divulgación y difusión de la obra literaria de Abraham ibn Ezrá, tanto en su faceta exegética-teológica como en la científica, y tanto en lengua hebrea como en latín.

En este artículo he examinado solamente la primera fase del proceso, pero hay que subrayar que se trata de una etapa inicial y que en los siglos posteriores -especialmente en el XIV, en el que acontece un verdadero «renacimiento» de Abraham ibn Ezrá en España ${ }^{93}$-continuará divulgándose el término astrológico mišpatim junto con la difusión de la obra y el pensamiento de Ibn Ezrá. Esa etapa rebasa los límites cronológicos de este artículo, pero sería apropiado analizarla en otra ocasión.

93 Véase al respecto en SIMON Interpreting la sección «The Ibn Ezra Renaissance in Spain» págs. 111-121. 


\section{RESUMEN}

En este artículo se establece que Abraham Ibn Ezrá desempeñó un papel exclusivo en la creación del término hebreo mišpatim con acepción astrológica y que asimismo cumplió un papel central en la creación del equivalente latino iudicia. Se señala también que si el término mišpatim se consolidó en las obras de Ibn Ezrá, ello se debe a que los significados de la palabra reflejaban facetas fundamentales de su concepción del mundo. También se demuestra que la creación del nuevo vocablo no es un hecho aislado sino que representa más bien un caso particular de un fenómeno general que caracteriza su obra literaria: la creación de un léxico científico hebreo, basado explícita y conscientemente en el vocabulario bíblico. Se señala asimismo que los términos mišpatim y iudicia con acepción netamente astrológica se infiltraron en el hebreo y en el latín medieval gracias a la difusión de la obra literaria de Abraham Ibn Ezrá.

\section{SUMMARY}

This article asserts that Abraham Ibn Ezra was the first to endow the Hebrew word mishpatim with a clear astrological meaning, and that he also played an important role in the creation of the parallel Latin word iudicia. It is indicated that the word mishpatim was extensively used by Ibn Ezra in its exegetical and scientific works, because the word faithfully reflected main aspects of his world vision. It is maintained that the creation of this word should not be seen as an isolated event but as a part of a more general pattern: the creation of a new Hebrew scientific terminology based on the biblical vocabulary. We reveal also that both words, mishpatim and iudicia, were introduced to the medieval Hebrew and Latin languages because of the direct intellectual influence that Ibn Ezra exerted after his death. 